\title{
History
}

\section{Peculiar Spirit and Brand Identity of the Human Anatomy Department}

\author{
Oksana Popadynets, Omelian Yurakh", Mykola Rozhko, Halyna Yurakh
}

Ivano-Frankivsk National Medical University, Ivano-Frankivsk, Ukraine

*Corresponding author: anatomy@ifnmu.edu.ua

The Department of Human Anatomy of IFNMU is known both in Ukraine and abroad, primarily as an anatomical museum, which serves not only for the acquisition of anatomical knowledge, but also for the aesthetic education of students. This combination of Science and Art was offered by Associate Professor Omelyan Yurakh, a former student of the art school, who had some experience, gained as a high school student while helping to organize the school art museum. The idea was supported by Oksana Popadynets, who is an aesthete by her nature and whose activity is aimed at innovative changes. We must honestly admit that if she did not support the idea of using art paintings, there would be no anatomical museum as it exists today. Both are firmly convinced that the presence of masterpieces

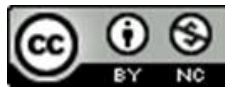

Copyright @Oksana Popadynets, Omelian Yurakh, Mykola Rozhko, Halyna Yurakh, 2020
Subiectum unicum studii hominem sapientem habent. Art and Anatomy have the one object of the study - Homo Sapiens.

of fine art at every Human Anatomy lesson will contribute not only to the formation of students' aesthetic perception of art, but also to their ability to feel, realize, unmistakably grasp the real surrounding world and admire, respect the beauty of its nature, the beauty of the language, the attractiveness of medical profession, the mutual assistance between colleagues, the ethical behavior in society, the noble relationships between people, the empathetic feeling for human grief, the heroic actions of a particular person and the nation as a whole. As future doctors, students will need this when communicating with colleagues and patients in the near future. We have found a fragment of the Sistine Chapel fresco in the Vatican "The Creation of Adam" by Michelangelo Buonarroti (Fig. 1), which depicts the perfect body of a man (front view). Next to Michelangelo's painting there is posted a painting by Spanish artist Diego Velázquez "Venus at her Mirror / Venus and Cupid" (also known as "The Toilet of Venus", "Venus at her Mirror", "Venus 


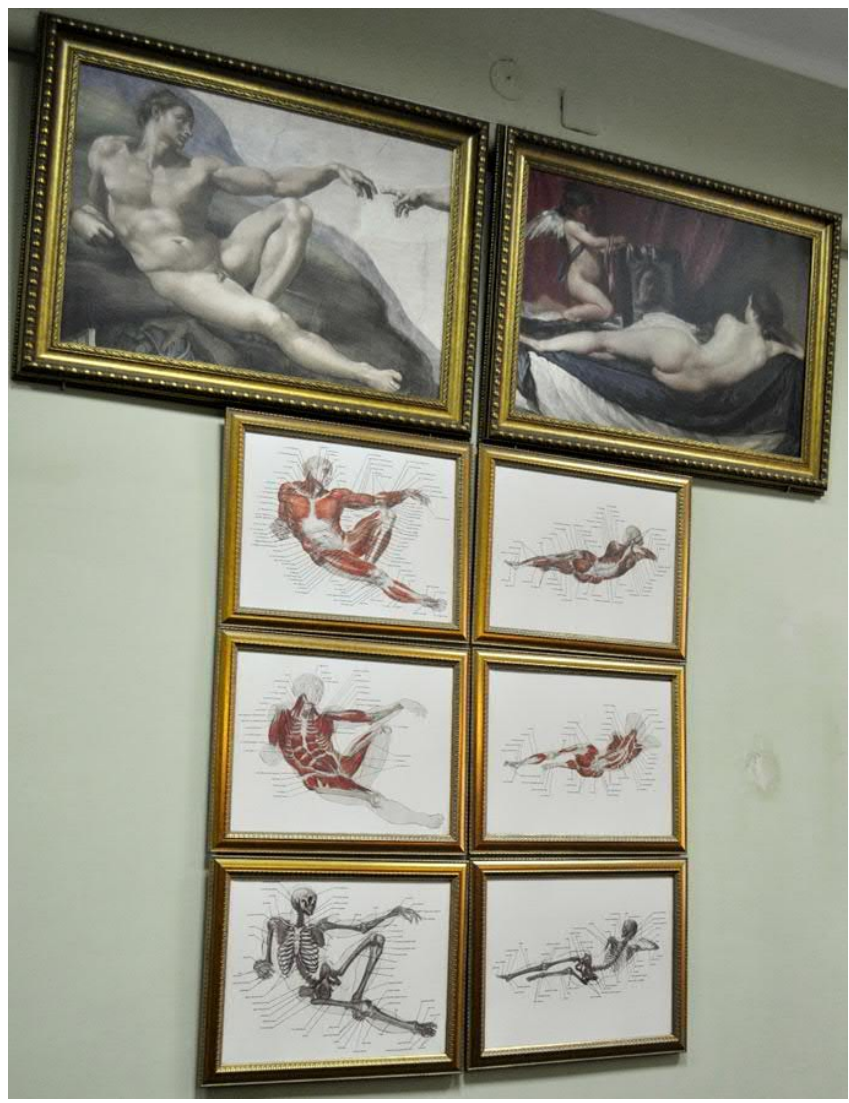

Figure 1. Michelangelo (1475-1564): a fragment of the fresco of the Sistine Chapel in the Vatican "The Creation of Adam" (1511). The body of the first person is young and beautiful, but the eyes are still soulless, and the Creator God transmits human energy into him through his right hand. In order to cheer up Adam, God created a woman by giving her the mystery, peculiar to goddess of love, Venus. The mystery of the woman is in her eyes and in a flirtatious smile. The mystery of a woman is in her tears and in her flesh, which reminds of a violin. And the famous Spanish artist Diego Velazquez, one of the famous lovelorns, knew good enough that the last mystery of a woman is best seen from the side of her back. Velazquez (1599-1660). The canvas "Venus at her Mirror/ Venus and Cupid"

was painted in Rome, where he was on a diplomatic mission (1647-1651).

and Cupid", or "La Venus del espejo"), which depicts a beautiful woman's body from the back. We have virtually "dissected" the bodies, depicted in the paintings. As a result, there were produced 6 colorful anatomical schemes of: superficial skeletal muscles, deep skeletal muscles and skeleton. Nadiya Tokaruk has spent a lot of time to sign every muscle and bone in small font in Latin. Students study staying closely to the schemes, and they are also used from afar in practical skills evaluation at the final module control.

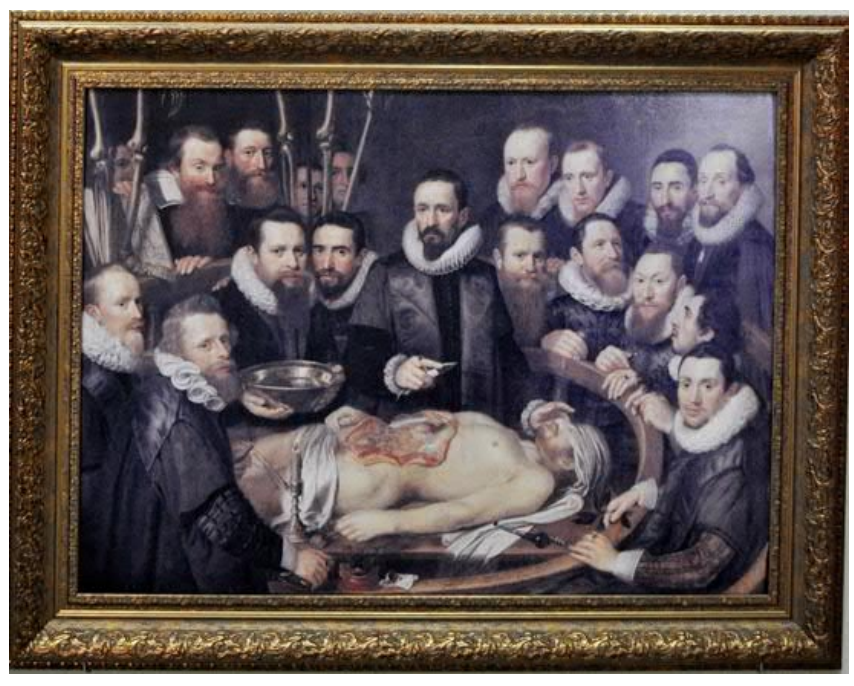

Figure 2. At the end of the sixteenth and during the seventeenth centuries, it was decided to organize public anatomical lessons in European countries. The day before, the criminals were executed publicly, and their bodies were provided for preparation by famous surgeons. The last ones invited famous artists to paint a group portrait of representatives of the surgical guild. Amsterdam

1617, the famous artist Michiel van Mierevelt (1566-1641), canvas "Anatomy lesson of Dr. Willem van der Meer", an example of painting crafts, is a color photograph, which has achieved portrait similarity, and nothing more.

A profoundly psychological painting "The Anatomy Lesson of Dr. Nicolaes Tulp" by Rembrandt (Fig. 3), which was on the wall in the office of the Department's founder Yukhym Melman, came to mind. A painting "Anatomy Lesson of Dr. Willem van der Meer" by artist Michiel van Mierevelt (Fig. 2) has been localized below it, being similar to color photography and nothing more. There was a place in the museum for the still life of the Dutch artist Peter Klas (Fig. 4), where each item is sacral- 


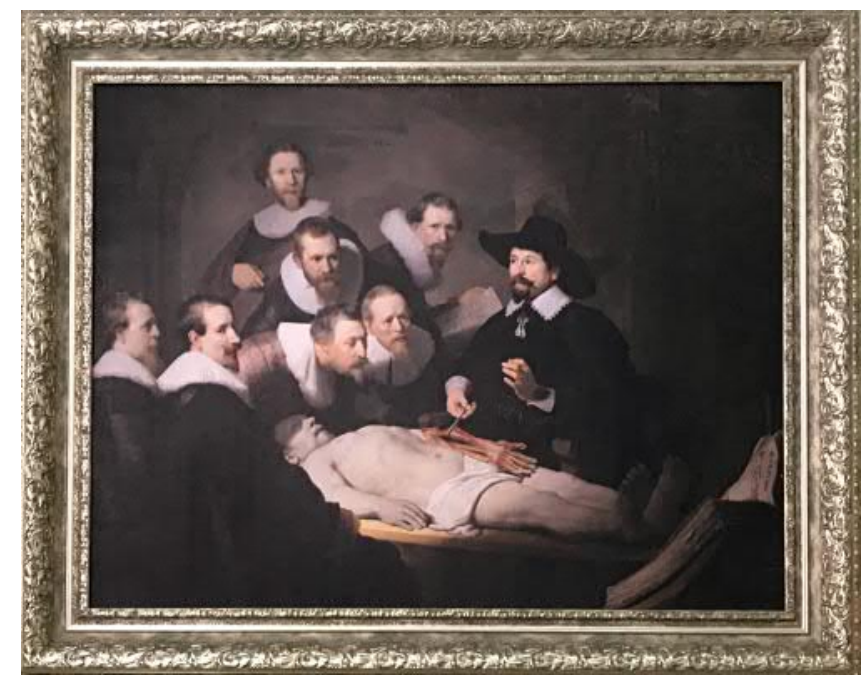

Figure 3. Amsterdam 1632. The criminal Aris Kindt was executed in January, and the body was given to a prominent surgeon Dr. Tulp, who asked unknown 26-year-old Rembrandt van Rhine to paint a group portrait. The artist managed to create the illusion of spectator participation in the event depicted in the painting. We opened the door, and a bright light fell on a motionless body and we came to Dr. Tulp's anatomy lesson. The two that stood higher payed attention to us. The second one on the left looked at us too. Tulp communicates with surgeons, but his eyes look through them. It gives the false impression that there were some other characters, too. This illusion of complete reality could only be created by a brilliant artist.

ized, but in total - it is a mention of the transience of being. The paintings of artists Gabriel von Max (Fig. 5) and Enrique Simonet (Fig. 6) reveal the theme of the death of a young beautiful woman who, according to American writer Edgar Allan Poe, is for certain the most poetic theme in the world.

Athletes, students, travelers, representatives of various professions, professors of medicine of the near and far abroad, of the Baltic States and of the North American countries unanimously declare that they have never seen such a successful and unexpected combination of fine arts and anatomical preparations.

The excursions are guided by the Head of the

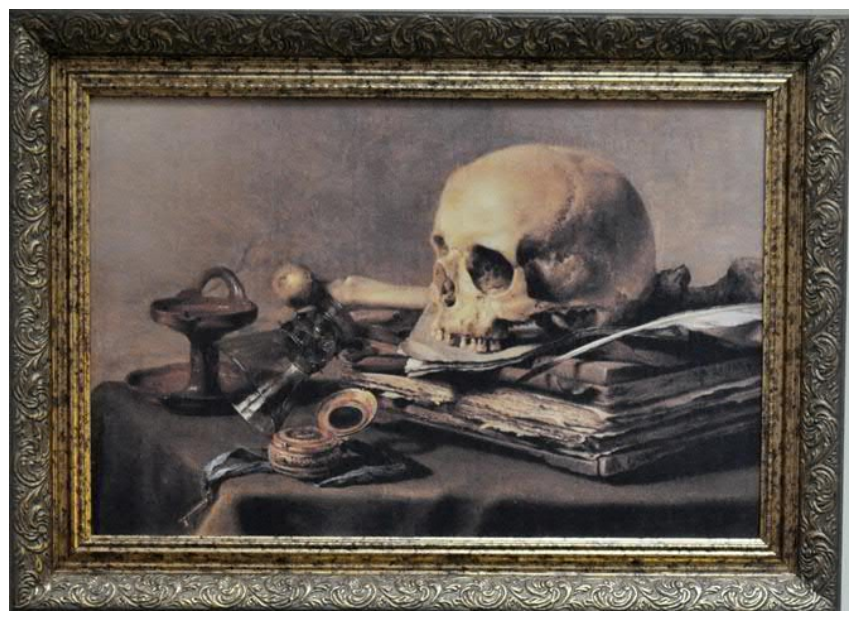

Figure 4. Peter Class (1597-1661). Still life "Still Life with a Skull and a Writing Quill". In the picture, every object is a symbol. The skull and bone are death. Goose feather is an unwritten letter to beloved one. A lot of paper symbolizes work in progress. An overturned glass without wine means a life, lived to the end. A stopped watch is a time you will not be able to return. And yet, there is no more necessary key, an unburnt cigarette. The composition as a whole sounds like Vanitas in

Latin and like the corruptness of being in Ukrainian.

Department, Professor Oksana Popadynets and Associate Professor Omelyan Yurakh (Fig. 7), and in English - by Assistant Professors Mariya Hryshchuk, Taras Kotyk and Assistant Liliya Sobol. During the excursion the natural connection between art and anatomy is explained; exemplarily prepared bones, organs and parts of the human body are illustrated; attention is paid to the harmfulness of eating poor quality food, alcoholism, drug addiction, smoking; the items of the meaning of life, the inevitability of death, the evanescence of youth, old age with its wisdom are discussed; the Heroes of the Revolution of Dignity and the Soldiers who perish in Eastern Ukraine for our existence, are honored. The number of excursions is increasing every year. There were 42 excursions from September till May in 20172018, then during the last academic year there were 56 of them.

The Anatomical Museum is also training-practical center, where doctors are provided with the con- 


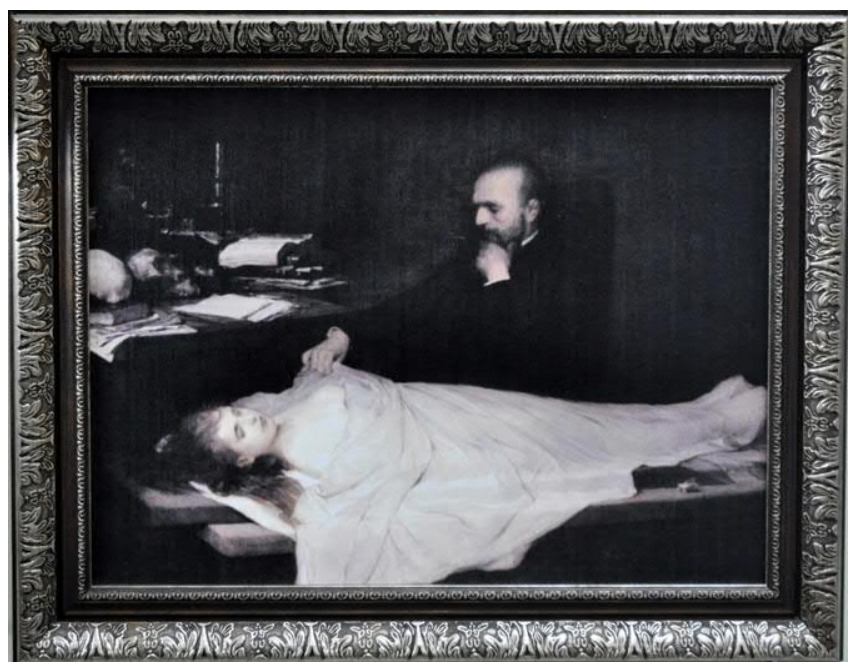

Figure 5. German artist

Gabriel Max (1840-1915). Painting "An

Anatomist". A thoughtful old anatomist is depicted in misty grayish-black. He is about to dissect a beautiful dead young woman, whose body is painted in sentimental, tragic but extremely harmonious tones.

ditions for preparation of embalmed physical bodies of people, if there is a necessity to study the anatomy of their single parts more deeply.

\section{And it all started with the reconditioning of the Department...}

Rector Mykola Rozhko, starting capital reparation and re-equipment of the basic departments, made Omelyan Yurakh responsible for reconstruction of the Human Anatomy Department. Initially, they've created the mini-vivarium within the Department, renovated the walls and reequipped the computer class, overhauled the laboratories of electron microscopy and histological research. In 2014 it was time to rearrange the former preparation room of the Municipal Pathology Department into the anatomical hall of the Human Anatomy Department. There was made a decision of moving the anatomical museum of the Department from the second floor to the first one and to create 4 study rooms on the area of the former museum. This helped to take away formaldehyde vapor, which is a dangerous cytoplasmic poison, from the study rooms to the anatomical room, thus reducing the contact time with formalin

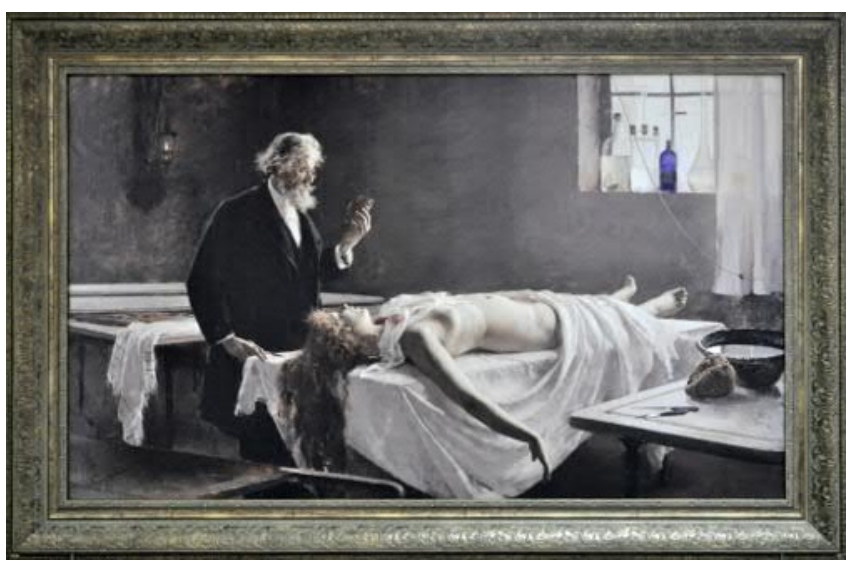

Figure 6. The Spanish artist Enrique Simone Lombardo (1866-1927). The worldwide recognition of the artist was brought to him by his painting "Anatomy of the Heart" (1890). Performed in the style of strict classical realism, it became monumental and at the same time tragic and sentimental. The contemplation of the angelic breathless body of a young woman really inspires...

It is the anthem of the complicated and difficult

work of the pathologist and the fear of the anatomist, the omnipotent master of the inner flesh of a man. The heart means a clear sacralization of death and all hidden from our view, namely the

reflections on the meaning of life. This is a message to future generations of all ages. When looking at this picture, we overthink the tragic events of the Revolution of Dignity and the horror of war in the Eeastern Ukraine. "She had a heart" says her other name ...

not only for teachers but also for students.

The walls and floor of the anatomical museum / hall underwent capital repair, the heating system was repaired, a new brettice at the entrance to the museum was performed in the Greek style. Preparation tables were repaired, and each of them was supplied with water and sewerage. Window ventilators have been replaced with two more powerful ones. There is good lighting in the rooms and in every cabinet. At the same time, restoration of old wooden museum cabinets was started adding a unique charm to the museum.

The museum became decent and functionally useful. Later there was the idea: "What about hang- 


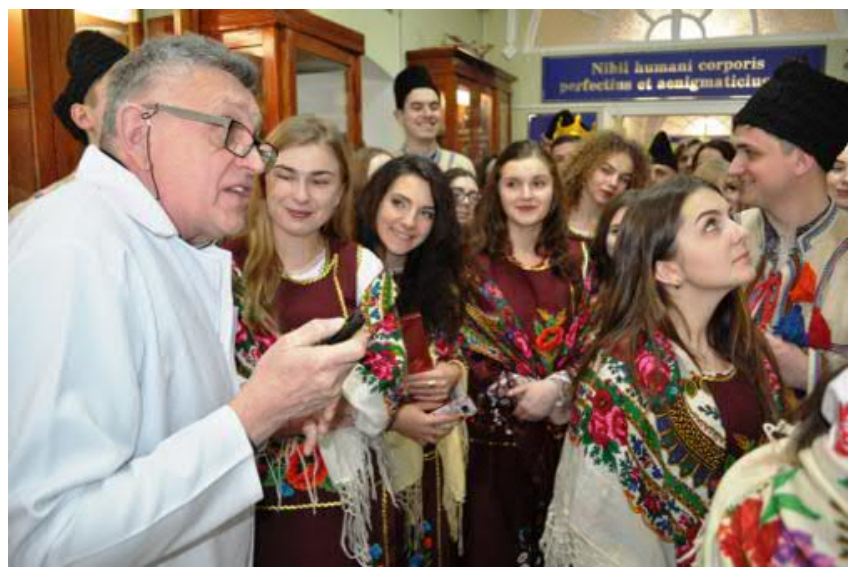

Figure 7. An excursion for students of Ternopil National Medical University named after Ihor Gorbachevsky. They congratulated the staff of the department on Christmas holidays (2018). This excursion was provided by Associate Professor

Omelyan Yurakh. Students were not bored!

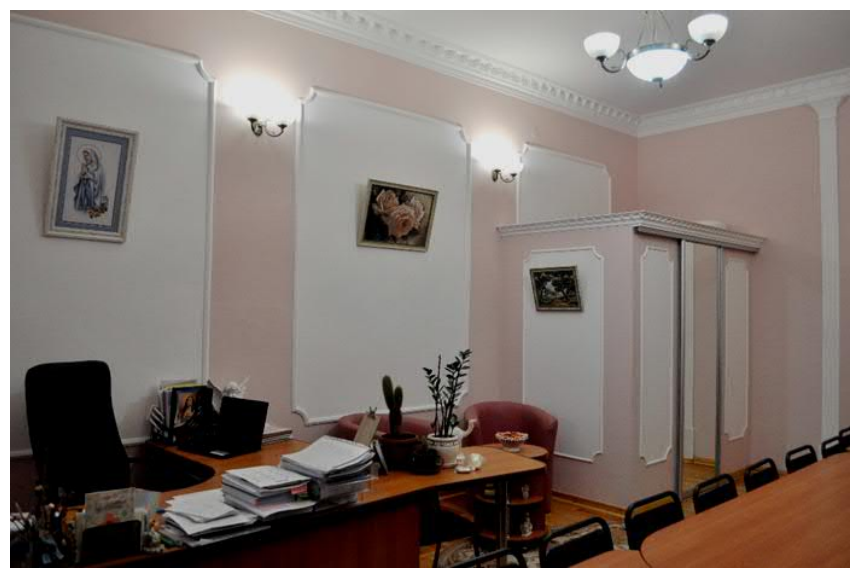

Figure 8. An office of the Head of the Department Oksana Popadynets. Ancient Greek style is performed in modern way. Pilasters, capitals, entablature, geometric decoration create an atmosphere of ancient science and ancient art, which inspires to do creative work.

ing the high-quality copies of paintings depicting the physical human body or the preparation of a human cadaver on the walls of the anatomical museum? Why not? After all, both Art and Human Anatomy have the same object of study - the body of Homo Sapiens". Thus, an extravagant and very popular Anatomical Museum appeared in its present form.

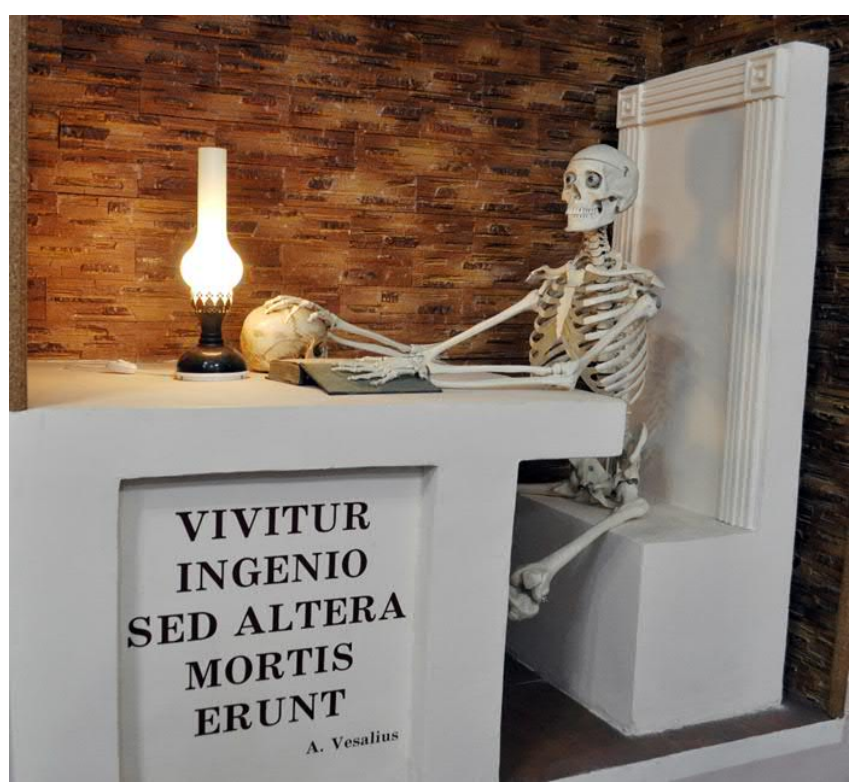

Figure 9. Skeleton sapiens - clever skeleton. He will know Anatomy perfectly! Rudolf Virhov's textbook of 1867 edition will help him to do this.

The presentation of the Anatomical Museum took place on the $29^{\text {th }}$ of September, 2015. The rector and the administration of the University, the members of the Academic Council from different parts of Ukraine, the delegates of the scientificpractical conference dedicated to the $75^{\text {th }}$ birthday anniversary of the prof. Shutka BV, everyone willing and many journalists came. Everyone liked it, everyone was delighted.

\section{But that wasn't the end...}

Following the museum, the repair and reconstruction of the working rooms began. The newly created classrooms and study rooms are very fascinating (Fig. 8), they were made in the style of "Antique", which is peculiar to the architecture of ancient Greece, with pilasters, capitals, entablatures, rectilinear profiles and geometric decor is of great admiration. In the Department Lecture Hall, there is "The Intelligent Skeleton", studying the Rudolf Virchow's textbook, published in 1867 (Fig. 9) in the German language. The rearrangement of few study rooms into "Artanatomy" style (Fig. 10, 11) brightens the mood and help a smile appear on a face. Another study room is dedicated to Leonardo da Vinci, so if you got into, you will immediately notice the 
all-seeing eyes of Mona Lisa (Fig. 12), you won't miss the equally well-known fresco "The Last Supper" and the variety of reproductions of anatomical drawings of the artist himself (Fig. 13). In another room there are drawings of the creator of modern anatomy Andreas Vesalius (Fig. 14) and his quotation that has been existed more than 5 centuries longer than its author: "Vivitur ingenio sed altera mortis erunt" (creation of the mind is eternal, and the rest obeys death) (Fig. 15).

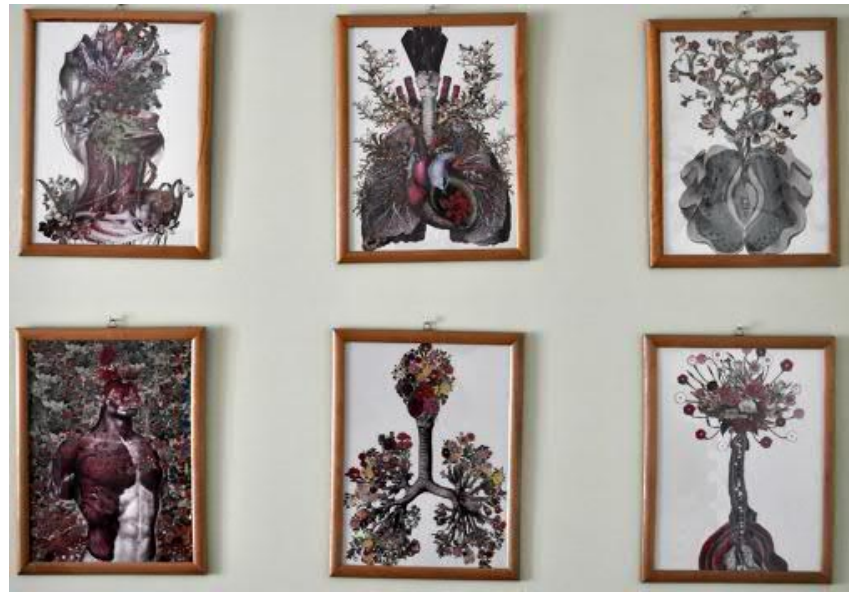

Figure 10. You are amazed at the diversity of the human body, not just of its soul!

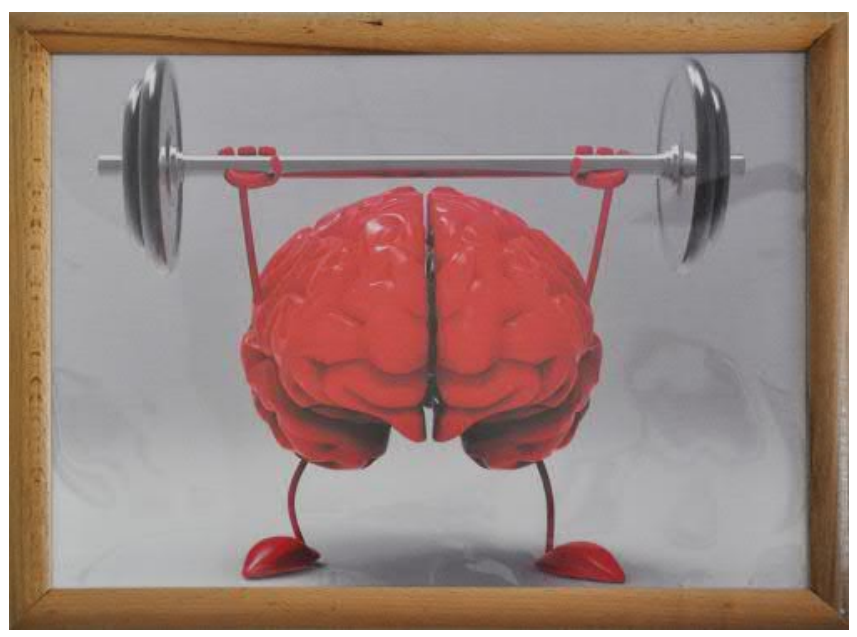

Figure 11. Sport not only strengthens the power of the muscles, but also the perseverance of mind.

The full repair of corridor of the Department began at the beginning of 2017 (Fig. 16). Oksana Popadynets suggested placing a copy of the

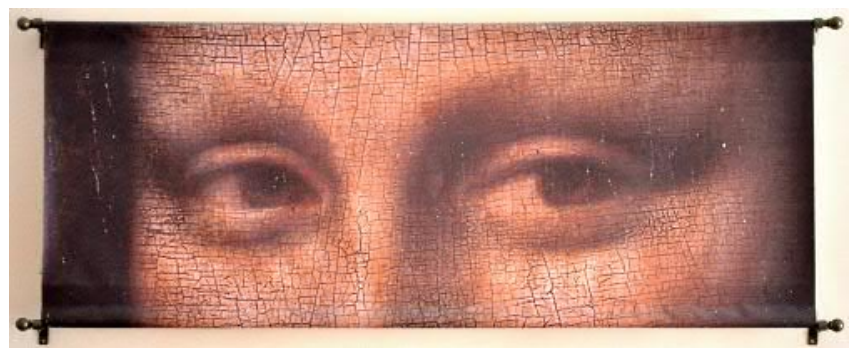

Figure 12. Leonardo da Vinci (1452-1519) "Mona Lisa (Joconda)" (1503). Wet eyes are sparkling as if they were alive. There is nowhere to hide from the sight of Joconda, it stubbornly follows you wherever you go.

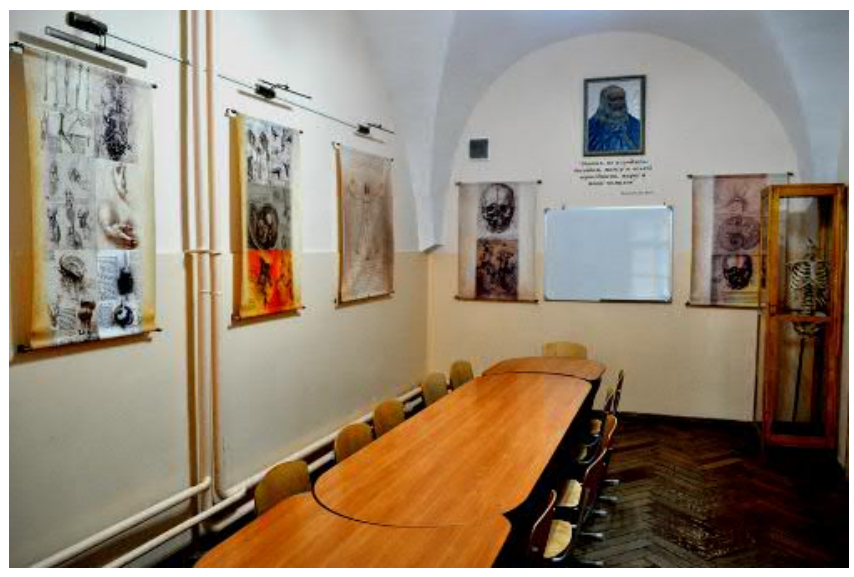

Figure 13. Leonardo da Vinci is an Italian artist and anatomist, sculptor and architect, musician and singer, writer and inventor, "universal" scientist. His statement," All sciences are vain and full of errors that are not born of Experience, the mother of all Knowledge," convinces us, that da Vinci was first and foremost an ingenious philosopher-materialist of the Renaissance.

statue of King David (Fig. 17), whose son, King Solomon, was located in the second position in the lineage of Jesus Christ. She also was in favor of putting a copy of the statue of Venus de Milo, which is the national pride of the French people. These statues are considered to be the ideal of male and female body on which students successfully study the contours of the muscles. The collages and copies of paintings, the contents of which reveal the history of anatomy from ancient times, were placed on the walls of the corridor (Fig. 18, 19, 20, 21, 22). The 


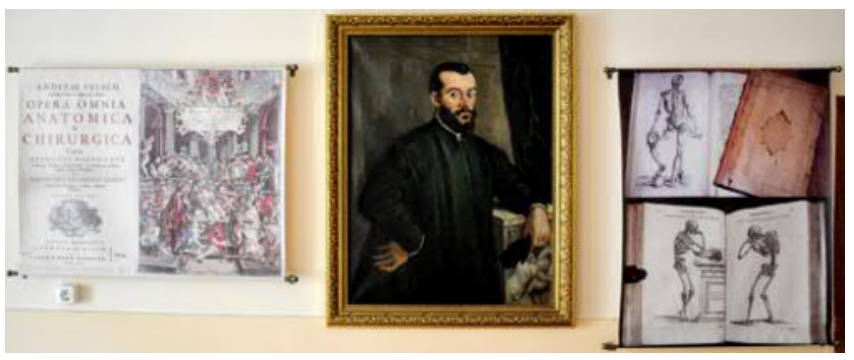

Figure 14. Andreas Vesalius (1578-1657) is a reformer of descriptive anatomy and a creator of scientific one. The incontrovertible evidence of the real structure of the human body has brought him worldwide fame. He fixed more than 200 errors of Galen. His life is a constant struggle in the name of victory of the "new" anatomy. He died infirm, forgotten by everyone on the island of Zante in Mediterranean Sea.

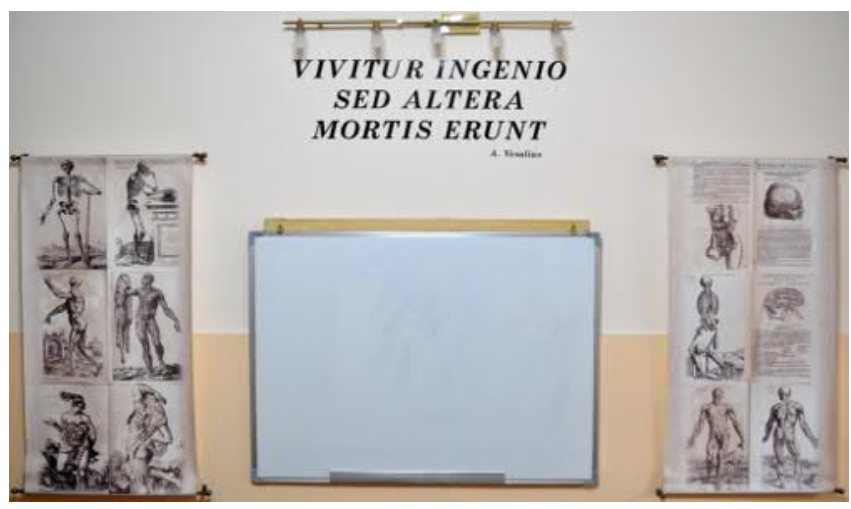

Figure 15. The anatomical paintings of A. Vesalius and his famous quotation: "Genius lives on, all else is mortal".

portrait gallery of outstanding scientists, who have made a significant contribution to the development of morphology, is also located here (Fig. 16); it was purchased by Yukhym Melman and carefully restored earlier. Mykola Rozhko, the rector of the university, once expressed the opinion while contemplating all this: "This should be not only the Department of Anatomy, but also the Anatomical Theater! ".

Therefore, let's create the Anatomical Theater, where the general director is the staff of the Department, the actors - are the characters from paintings, the spectators - are the students, doctors,

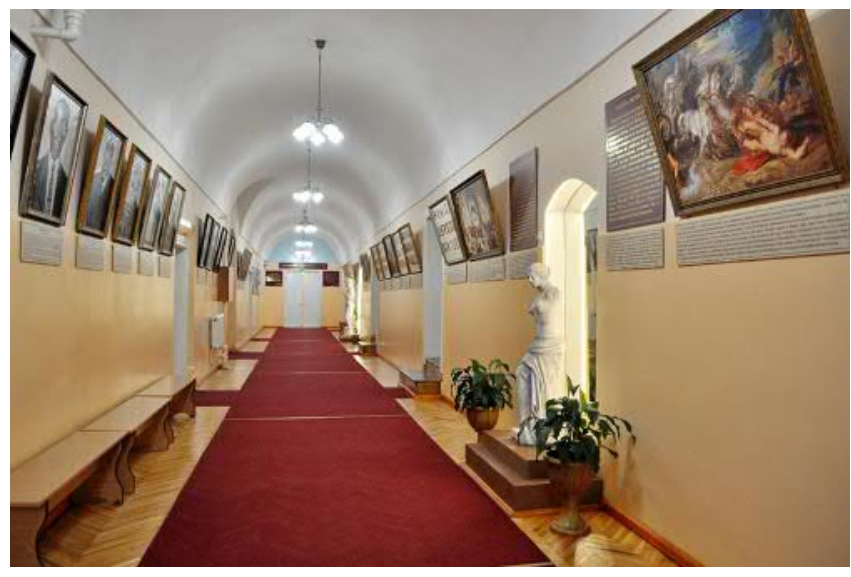

Figure 16. This is not only an art gallery or an art room - it is IFNMU anatomical theater, which is not restricted to this space. If you want to see more, then take a look at every study room, at every office. You will not regret it!

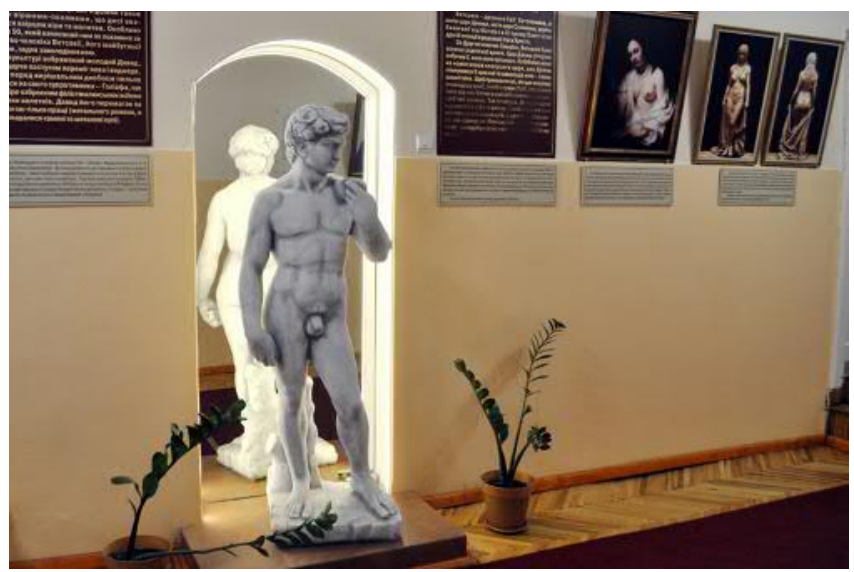

Figure 17. A copy of Michelangelo's statue (1501-1504), which is a symbol of the Renaissance. King David is known not only for his own exploits in the struggle for the independence of his people, not only for his psalms, which are still recognized as a model of faith and praying, but he is also a father of King Solomon, who is on the second place in the genealogy of the Son of God.

visitors of the museum, and the ovations - are the emotions which burst during the excursions.

Come, watch, listen, perceive and enjoy.

Received: $2020-05-14$

Accepted: 2020-05-17 


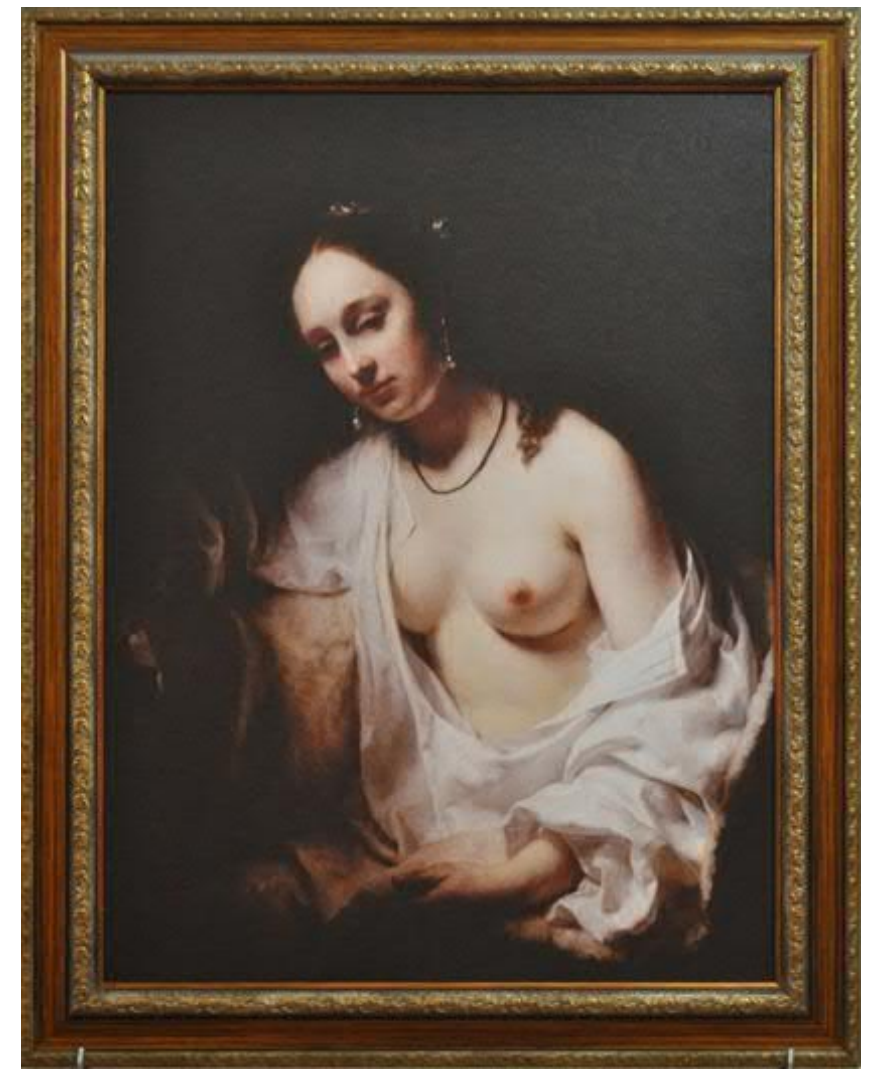

Figure 18. The Dutch artist Willem Drost (1633-1659), one of Rembrandt's most talented students, the painting "Bathsheba" (1654). According to the second book of Samuel, Bathsheba was a woman of rare beauty, so it is not surprising that King David was tempted by her charms, and she became his second wife and mother of his second son Solomon, crowned by his father.

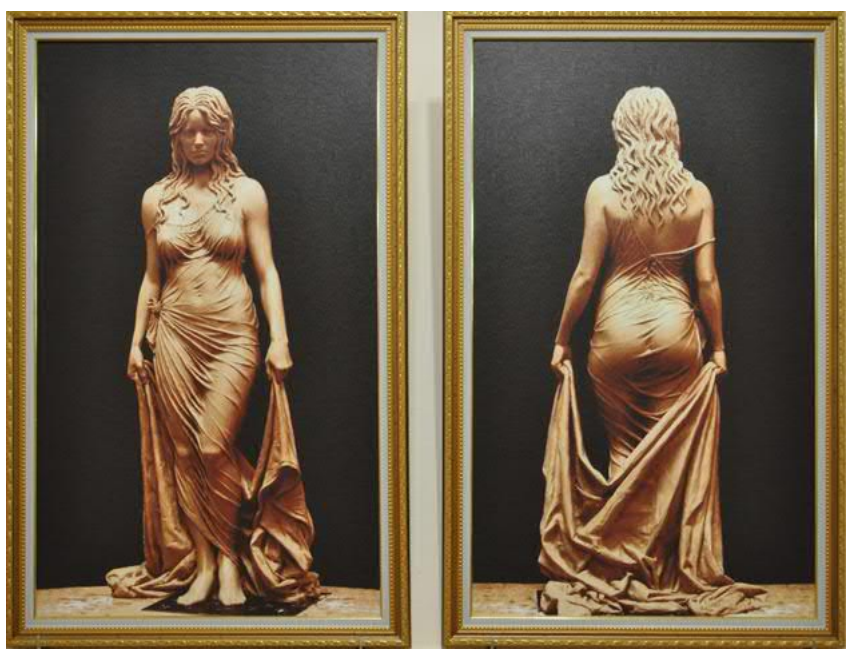

Figure 19. American sculptor Benjamin Matthew Victor, born in 1979. Bathsheba just came out of the water. The lacy folds of transparent clothing are striking to emphasize the beauty of her body. So natural. Is it only bronze... 


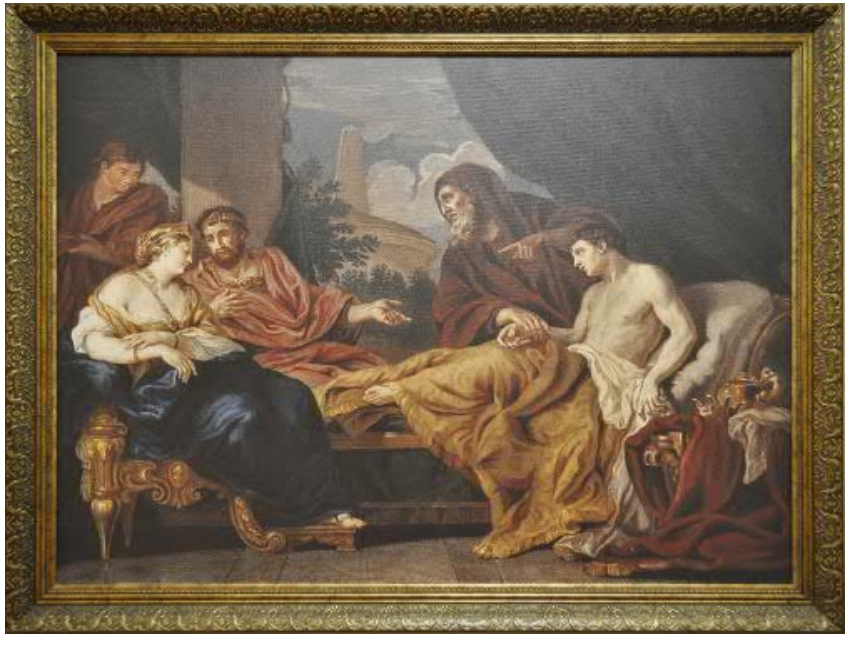

Figure 20. Italian artist Luca Giordano (1632-1705). A canvas "Antiochus and Stratonice" tells us the story of the love of King Seleucus, the founder of the Syrian Kingdom, to Stratonice.

Antiochus is the king's son by his first wife.

Stratonice is Seleucus' second wife, a young beautiful woman, who is 40 years younger than him. The picture shows a moment when the Greek doctor Erasistratus identifies the cause of Antiochus' severe depression and announces to Seleucus, that his son's illness is an overwhelming passion for king's young wife. Erasistratus advises him to make a wise decision. Seleucus divorces Stratonice and married Stratonice off to Antiochus. The artist brilliantly reproduced the inner spiritual state of each character on their faces: suffering is noticeable on the face of Antiochus; confidence Erasistratus; disappointment - Seleucus; reflection Stratonice; curiosity - the servant. Students are encouraged to indicate which facial muscles are responsible for emotional expressions on each person's face on the canvas.

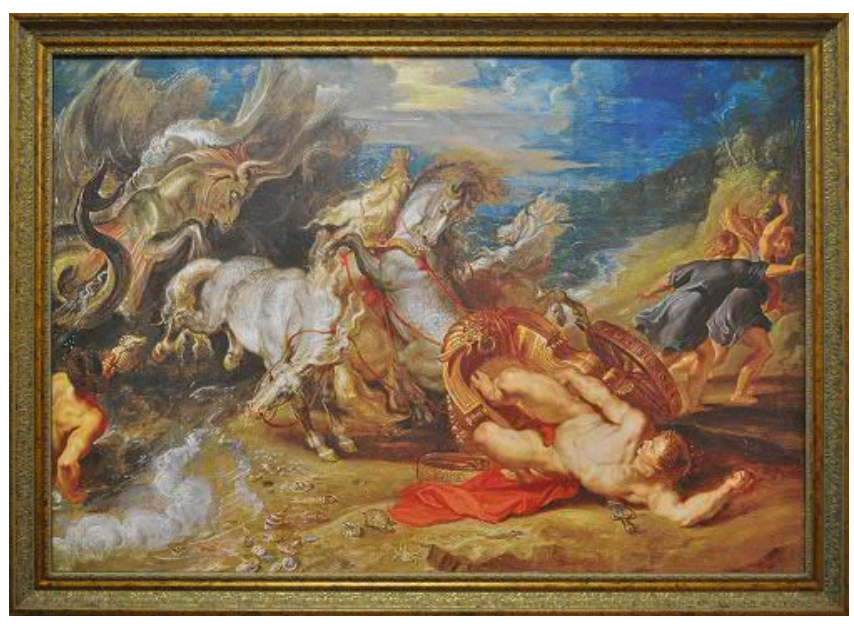

Figure 21. Peter Paul Rubens (1577-1640) "The Death of Hippolytus". This is one of the most famous fatal accidents. However, it is not an accident, but a crime, a horrific murder because of jealousy, hatred and thirst for revenge. According to Greek mythology, the goddess of love, Aphrodite, hated Hippolytus, the son of King Theseus, who ruled in ancient Athens, for neglecting her love. She brought on Phaedra,

Theseus' second wife, an irresistible and all-consuming passion for her stepson. After getting to know, that Hippolytus had rejected her, Phaedra committed suicide, writing in a suicide note that the stepson had sought her, which caused Theseus to be angry. He drove his native son out of the country and asked the sea god to kill him. Poseidon sent the monster from the depths with the tail of a snake, the head of a horse, the horns of a bull, the legs of a frog. The horses were frightened, lost, the chariot crashed... Hippolytus was killed. All who have fallen into this weaked love cycle have suffered because of a tangle of unquenchable passions. The painting of Rubens teaches to subordinate actions and feelings to our mind. 


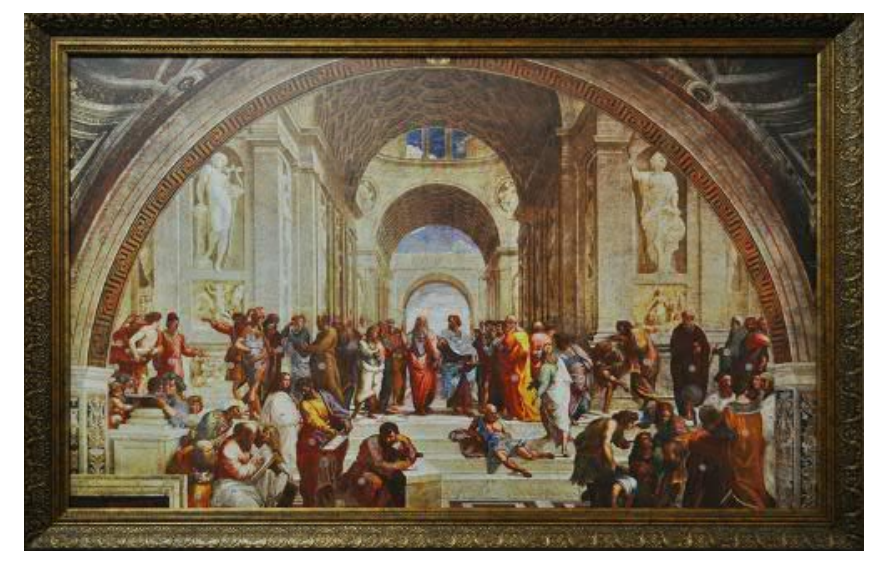

Figure 22. Raphael Santi (1483-1520) "School of Athens" (1511). One of the frescoes of the ceremonial stanzas of the Vatican Palace. In the center of the stairs idealist Plato points on the sky with his right hand; there he sees the essence of being and knowing. He is contradicted by the materialist Aristotle, whose palm is open to the earth. There are many wise men around. They discuss the problems of different directions of philosophy and different sciences. They are all united by the idea of humanism. 